\title{
Prevalence of hepatitis B and C among students of health colleges in Saudi Arabia
}

A. Al-Ajlan

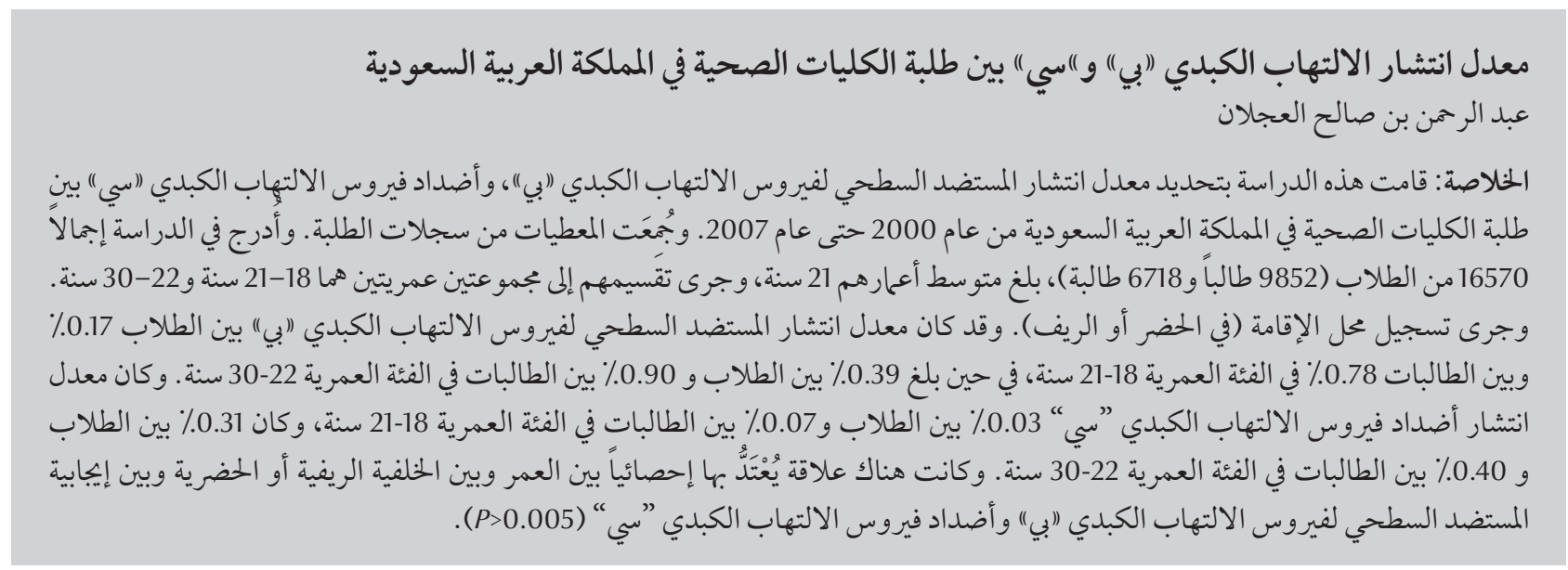

ABSTRACT This study determined the prevalence of hepatitis B surface antigen $\left(\mathrm{HB}_{\mathrm{s}} \mathrm{Ag}\right)$ and antibody to hepatitis $\mathrm{C}$ virus (anti-HCV) among students at health colleges in Saudi Arabia from 2000 to 2007. Data were obtained from student records. A total of 16570 (9852 male and 6718 female) students were included. Their mean age was 21.years and they were divided in 2 age groups of 18-21 and 22-30 years. Residence (rural or urban) was recorded. The prevalence of $\mathrm{HB}_{\mathrm{s}} \mathrm{Ag}$ for males and females was $0.17 \%$ and $0.78 \%$ respectively in the $18-21-y e a r-$ olds and $0.39 \%$ and $0.90 \%$ in the $22-30$-year-olds. The prevalence of anti-HCV for males and females was $0.03 \%$ and $0.07 \%$ respectively in the $18-21$-year-olds and $0.31 \%$ and $0.40 \%$ in the $22-30$-year-olds. There was a statistically significant relationship between age and rural/urban background and $\mathrm{HB}_{\mathrm{s}} \mathrm{Ag}$ and anti-HCV positivity $(P<0.005)$.

\section{Prévalence de l'hépatite $B$ et $C$ chez des étudiants en faculté de santé en Arabie saoudite}

RÉSUMÉ La présente étude a déterminé la prévalence de l'antigène de surface de l'hépatite $B\left(\mathrm{HB}_{\mathrm{s}} \mathrm{Ag}\right)$ et des anticorps du virus de l'hépatite C chez des étudiants en faculté de santé en Arabie saoudite entre 2000 et 2007. Les données ont été collectées à partir des dossiers des étudiants. Au total, 16570 étudiants (9852 hommes et 6718 femmes) ont participé à l'étude. Leur âge moyen était de 21 ans et ils ont été répartis dans deux groupes d'âge de 18 à 21 ans et de 22 à 30 ans. Le lieu de résidence, rural ou urbain, a été noté. La prévalence de l'antigène de surface de l'hépatite B chez les hommes et les femmes était de 0,17\% et 0,78\% respectivement dans la tranche d'âge de 18 à 21 ans et de 0,39\% et 0,90\% dans la tranche d'âge de 22 à 30 ans. La prévalence des anticorps du virus de l'hépatite $\mathrm{C}$ chez les hommes et les femmes était de 0,03\% et 0,07\% respectivement dans la tranche d'âge de 18 à 21 ans et de 0,31 \% et 0,40 \% dans la tranche d'âge de 22 à 30 ans. Un lien statistiquement significatif a été établi entre l'âge, l'origine rurale ou urbaine, et la positivité de l'antigène de surface de l'hépatite B ou des anticorps du virus de l'hépatite $C(P<0,005)$. 


\section{Introduction}

Approximately 350 million people are infected by Hepatitis B virus (HBV) globally. A large number become positive for hepatitis $B$ surface antigen $\left(\mathrm{HB}_{\mathrm{s}} \mathrm{Ag}\right)$ but they remain asymptomatic. They are known as silent carriers of HBV [1] and may act as a source of transmission of hepatitis B. In high and moderate prevalence zones of HBV, like South Asia and the Middle East, many silent carriers are young people $[2,3]$.

The prevalence of HBV has declined considerably in Saudi Arabia since the introduction of immunization in 1989. According to one study, it fell from $7 \%$ in 1989 to $0.3 \%$ in 1997 [4]. A study 8 years after the introduction of hepatitis $B$ vaccination reported seroconversion of $77 \%$ in children vaccinated at birth and $71 \%$ in those vaccinated at school entry [5]. Jaber reported in 2006 [6] that $98 \%$ of schoolchildren in Jeddah, Saudi Arabia were covered by HBV vaccination; however $14 \%$ of students tested negative for anti- $\mathrm{HB}_{s}$ antibodies, suggesting that the efficacy of HBV vaccination is diminishing with increasing age [6]. It has been reported that the prevalence of HBV among blood donors in Saudi Arabia decreased from $2.7 \%$ in 1993 to $0.28 \%$ in $2003[4,7,8]$.

Hepatitis C virus (HCV) infection affects around 170 million people worldwide $[3,4,9]$. The prevalence of hepatitis $\mathrm{C}$ is lower than hepatitis $\mathrm{B}$ but in certain regions, for example Egypt, the prevalence of hepatitis $\mathrm{C}$ is much higher than hepatitis B [10-12]. Carriers of hepatitis $C$ have antibodies to the virus (anti-HCV). Although the number of $\mathrm{HCV}$ carriers is small compared to the total number of people infected with $\mathrm{HCV}$, they can still transmit the virus $[11,12]$.

The prevalence of $\mathrm{HBV}$ varies significantly across the world, being the lowest in Western European countries and the United States with a range of $0.1 \%-2.4 \%$ and highest in Africa with a range of $2.2 \%-22.6 \%$ [13-21]. It has been observed that hepatitis B is more prevalent among the young population compared to hepatitis C [22].

Many studies have been carried out in Saudi Arabia on the prevalence of hepatitis $B$ among children in the age group 1-10 years, and hepatitis B and $\mathrm{C}$ among the general population and healthy blood donors $[4,5,11,12,23$ 28], but none has targeted college and university students. However, the prevalence of $\mathrm{HBV}$ and $\mathrm{HCV}$ in college students may give and indication of the effectiveness of the measures and the prophylactic programmes applied to younger age groups. Therefore, this study concentrated on the determining the prevalence of hepatitis B and C among students admitted to the health colleges of Saudi Arabia.

\section{Methods}

Data were collected from the files of newly admitted students (freshmen) from the colleges and health institutes located in different regions of Saudi Arabia. Thus 9852 male and 6718 female students (total 16 570) admitted to 12 male and 17 female health colleges and institutes from 2000 to 2007 were included in the study. Data on students' age, place of birth, rural or urban background, and the results of serological testing done for hepatic $\mathrm{B}$ and $\mathrm{C}$ at the time of admission were retrieved from the files of students at the colleges. As a policy in Saudi Arabia all new students admitted to health colleges have undergo a thorough medical check-up and serological testing for $\mathrm{HB}_{5} \mathrm{Ag}$, anti$\mathrm{HCV}$ and anti-HIV. All the serological tests for $\mathrm{HB}_{s} \mathrm{Ag}$, and anti-HCV tests are done with second and third generation ELISA kits (Roche laboratories).

Students who test positive for either hepatitis $\mathrm{B}$ or $\mathrm{C}$ are admitted only onto courses, such as administration or pharmacy, where they will not come in direct contact with patients.

\section{Ethical issues}

Each student was given a leaflet explaining the purpose of the research and stating that all the names and personal data would be decoded and participation was voluntary. Written consent was obtained from every student; 11 students declined to participate.

\section{Statistical analysis}

Regression analysis was carried out, with age group/residential background (urban/rural) as independent variables and $\mathrm{HB}_{\mathrm{s}} \mathrm{Ag} / \mathrm{Anti}-\mathrm{HCV}$ status as dependent variables. The regression coefficient and 95\% confidence intervals are presented. The $z$ test was applied to compare the sex ratio of male and female positive cases for $\mathrm{HB}_{\mathrm{s}} \mathrm{Ag}$ and anti-HCV.

\section{Results}

The total number male and female students admitted during the period was 9852 and 6718 respectively, in spite of the fact more female colleges (17) were included than male colleges (12)

The mean age of male students was 21.1 years and of females was 21.3 years. The students were divided into 2 age groups: $18-21$ years and $22-30$ years. There were 6268 (63.6\%) male and 4486 (66.8\%) female students in the18-21year-old age group, and 3584 (36.4\%) male and 2232 (33.2\%) female students in the 22-30-year-old age group.

Table 1 shows the distribution of the HBV-and HCV-positive students by sex and age group. There were significantly higher proportions of $\mathrm{HB}_{\mathrm{s}} \mathrm{Ag}$ positive and anti-HCV-positive cases in the 22-30-year-old age group than the younger age group for both males and females $(P<0.005)$.

Furthermore, a significantly greater proportion of female students were positive in both age groups and for both markers of $\mathrm{HB}_{\mathrm{s}} \mathrm{Ag}$ and anti-HCV compared to males $(P<0.001)$ (Table 1$)$.

Regression analysis demonstrated a declining trend of $\mathrm{HB}_{\mathrm{s}} \mathrm{Ag}$ carrier state in 


\begin{tabular}{|c|c|c|c|c|c|c|c|c|}
\hline \multirow[t]{4}{*}{ Hepatitis marker } & \multicolumn{8}{|c|}{ Age group (years) } \\
\hline & \multicolumn{4}{|c|}{$18-21$} & \multicolumn{4}{|c|}{$22-30$} \\
\hline & \multicolumn{2}{|c|}{ Males $(n=6268)$} & \multicolumn{2}{|c|}{ Females $(n=4486)$} & \multicolumn{2}{|c|}{ Males $(n=3584)$} & \multicolumn{2}{|c|}{ Females $(n=2232)$} \\
\hline & No. & $\%$ & No. & $\%$ & No. & $\%$ & No. & $\%$ \\
\hline $\mathrm{HB}_{s} \mathrm{Ag}$ & 11 & 0.17 & 35 & 0.78 & 14 & 0.39 & 20 & 0.90 \\
\hline Anti-HCV & 2 & 0.03 & 3 & 0.07 & 11 & 0.31 & 9 & 0.40 \\
\hline
\end{tabular}

$H B_{s} A g=$ hepatitis B surface antigen.

$H C V=$ hepatitis $C$ virus.

the younger age group. Among males and females, $0.17 \%$ and $0.78 \%$ respectivelywere $\mathrm{HB}_{5} \mathrm{Ag}$-positive in the 18-21year-old age groups, while $0.39 \%$ and $0.90 \%$ respectively were $\mathrm{HB}_{\mathrm{s}} \mathrm{Ag}$-positive in the 22-30 year-old age group. The proportion of anti-HCV positive cases was higher in the older age group of 22-30 years. There was no significant difference in the proportion of anti$\mathrm{HCV}$ positive cases between males and females.

Table 2 shows the distribution of hepatitis $\mathrm{B}$ and $\mathrm{C}$ positive cases by sex and urban or rural background. Data were missing for 3 males and 5 females positive for $\mathrm{HB}_{\mathrm{s}} \mathrm{Ag}$ and 1 female antiHCV positive about their place of origin. The proportion of cases positive for hepatitis $\mathrm{B}$ and $\mathrm{C}$ among males was significantly higher in students from rural background compared to urban $(P<0.001)$. The proportion of female students positive for hepatitis B did not differ significantly by background $(P<0.004)$, but the proportion of hepatitis $\mathrm{C}$-positive females students from rural background (58.3\%) was almost double that of hepatitis C-positive femalesstudentsfromurbanareas (33.3\%) $(P<0.001)$.

\section{Discussion}

The present study was carried out with the same method as the previous ones from Saudi Arabia, Italy, Taiwan, Poland and Egypt $[4,13-16,20,21]$. The mean age for males and females was almost the same (about 21 years) so we divided the students in two study groups of 18-21 years and 22-30 years. The percentage of male students in the older age group of 22-30 years was higher than female students, possibly because women are married at a much younger age in Saudi Arabia and only a few join college at a later age.

The present study shows that the prevalence of hepatitis $B$ and $C$ markers in both sexes among the students admitted in the health colleges and institutes in Saudi Arabia is lower than the general population (1.4\% for hepatitis B and over $1.5 \%$ for hepatitis C) [28].

The correlation with age and positivity for $\mathrm{HB}_{3} \mathrm{Ag}$ and anti-HCV in our study is similar to other studies carried out in different parts of the world $[13,15,16]$. Although the vaccination programme against hepatitis B in Saudi Arabia is quite comprehensive, it has been observed that seronegativity for anti- $\mathrm{HB}_{\mathrm{s}}$ increases with age. The higher number of $\mathrm{HB}_{\mathrm{s}} \mathrm{Ag}$-positive cases in the older age group (22-30 years) in the present study suggests that the older students entered school before 1990, when the hepatitis B immunization was first introduced at the school entry level, and they were not covered under the Expanded Programme on Immunization (EPI). A study carried out by Al Faleh et al. [5] assessed the efficacy of hepatitis B vaccination 8 years after EPI was launched but the test for anti- $\mathrm{HB}_{\mathrm{s}}$ and its titre was not included in the panel of screening tests for the newly admitted students or for the general population. No records were available in the college files about the vaccination status of the students and results of anti- $\mathrm{HB}_{\mathrm{s}}$ so the efficacy of hepatitis $B$ vaccination in the student population could not be assessed.

The higher prevalence of hepatitis $B$ carrier state in the female students compared to the male students in our study is in contrast to the findings of Su et al. [15] Due to some sociocultural factors of Saudi society, the girls may not have benefited properly from the antihepatitis $B$ vaccination programme.

Saudi Arabia is considerate to have a moderate to low prevalence of hepatitis

\begin{tabular}{|c|c|c|c|c|c|c|c|c|}
\hline \multirow[t]{3}{*}{ Hepatitis marker } & \multicolumn{4}{|c|}{ Urban } & \multicolumn{4}{|c|}{ Rural } \\
\hline & \multicolumn{2}{|c|}{ Males } & \multicolumn{2}{|c|}{ Females } & \multicolumn{2}{|c|}{ Males } & \multicolumn{2}{|c|}{ Females } \\
\hline & No. & $\%$ & No. & $\%$ & No. & $\%$ & No. & $\%$ \\
\hline $\mathrm{HB}_{\mathrm{s}} \mathrm{Ag}(\mathrm{M}=25, \mathrm{~F}=55)$ & 8 & 32.0 & 26 & 47.3 & 14 & 56.0 & 24 & 43.6 \\
\hline Anti-HCV $(\mathrm{M}=13, \mathrm{~F}=12)$ & 5 & 38.5 & 4 & 33.3 & 7 & 53.8 & 7 & 58.3 \\
\hline
\end{tabular}

Data on place of origin were missing for 3 males and 5 females positive for $\mathrm{HB}$ Ag and 1 female anti-HCV positive. $M=$ male; $F=$ female; $H B_{s} A g=$ hepatitis $B$ surface antigen; $H C V=$ hepatitis $C$ virus. 
$B$ and C $[27,28]$. The present study corresponds well with all the previous studies, which show that the prevalence of hepatitis $C$ increases with the advancing age $[13,14,27]$.

The declining trend of hepatitis $B$ in the Saudi population is attributed to the growing literacy rate, improving housing and hygienic conditions.

In contrast to previous reports from Saudi Arabia [5], the relationship shown for place of origin (rural or urban) with HBV and HCV infection is quite strong in the present study. More $\mathrm{HB}_{\mathrm{s}} \mathrm{Ag}$-positive cases were from rural areas suggesting of poorer vaccination coverage of the rural population. The higher prevalence of anti-HCV in students from a rural background is similar to the findings of El-Gilany et al. from Egypt [21], the country that reports the highest prevalence of hepatitis $\mathrm{C}$ in the world [27].
The present study shows very low prevalence of hepatitis $\mathrm{B}$ and $\mathrm{C}$ carrier state among the students of health colleges and institutes in Saudi Arabia. It is recommended that screening of antihepatitis $\mathrm{B}$ core antigen $\left(\mathrm{HB}_{\mathrm{c}}\right)$ be included in the screening profile of newly admitted students in order to detect occult cases of HBV that show negative $\mathrm{HB}_{s} \mathrm{Ag}$ and anti- $\mathrm{HB}_{\mathrm{s}}$ and to assess immunization status and the efficacy of the vaccination against hepatitis $B$.

\section{References}

1. Tong $\mathrm{S}$ et al. Hepatitis B virus e antigen variants. International Journal of Medical Sciences, 2005, 2:2-7.

2. Chaudhuri SK. HB Ag positivity rate amongvoluntary \& replacement donors in the IRCS blood bank. Indian Journal of Gastroenterology, 1999, 18:S21 [abstract].

3. FitzSimons $D$ et al. Hepatitis $B$ virus, hepatitis $C$ virus and other blood-borne infections in healthcare workers: guidelines for prevention and management in industrialised countries. Occupational and Environmental Medicine, 2008, 65:446-451.

4. Al-Faleh FZ. Changing pattern of hepatitis viral infection in Saudi Arabia in the last two decades. Annals of Saudi Medicine, 2003, 23:367-371.

5. Al-Faleh FZ et al. Seroepidemiology of hepatitis B virus infection in Saudi children 8 years after a mass hepatitis B vaccination programme. Journal of Infection, 1999, 38:167-170.

6. Jaber SM. Prevalence of anti-hepatitis B and anti-hepatitis A antibodies among school aged children in Western Saudi Arabia. Saudi Medical Journal, 2006, 27:1515-1522.

7. Shatoor AS, Zafer MH. Hepatitis B virus markers in male blood donors. Bahrain Medical Bulletin, 2002, 24:1-6.

8. El-Hazmi MM. Prevalence of HBV, HCV, HIV-1, 2 and HTLV-I/ Il infections among blood donors in a teaching hospital in the Central region of Saudi Arabia. Saudi Medical Journal, 2004, 25:26-33.

9. Te HS, Jensen DM. Epidemiology of hepatitis B and C viruses. A global overview. Clinics in Liver Disease, 2010, 14(1):1-21.

10. Abdel-Aziz F et al. Hepatitis C virus (HCV) infection in a community in the Nile Delta: population description and HCV prevalence. Hepatology (Baltimore, Md.), 2000, 32:111-115.

11. Darwish MA et al. Risk factors associated with a high seroprevalence of hepatitis $\mathrm{C}$ virus infection in Egyptian blood donors. American Journal of Tropical Medicine and Hygiene, 1993, 49:440-447.

12. Bassily $\mathrm{S}$ et al. A high risk of hepatitis c infection among Egyptian blood donors: The role of parental drug abuse. American Journal of Tropical Medicine and Hygiene, 1995, 52:503-505.

13. Bruno A et al. Prevalenza dei marcatori dell'epatite B negli studenti dei corsi di laurea in medicina [Prevalence of virus hepatitis B markers among medical students]. Giornale Italiano di Medicina del Lavoro Ed Ergonomia, 2007, 29(Suppl.):752-754.

14. Beggio $M$ et al. Prevalenza dei marcatori dell'epatite (A, B e C) in relazione alla provenienza geografica degli studenti dei corsi di laurea in medicina [Prevalence of hepatitis virus A, B, and $\mathrm{C}$ markers according to the geographic origin of medical students]. Giornale Italiano di Medicina del Lavoro Ed Ergonomia, 2007, 29(Suppl.):745-747.
15. Su FH et al. Forecasting the declining rate of chronic hepatitis-B carrier status at a Taiwanese university: twenty years after implementation of an universal HBV vaccination program in Taiwan. Chang Gung Medical Journal, 2007, 30:521-528.

16. Chen CC et al. Epidemiology of hepatitis B virus infection among young adults in Taiwan, China after public vaccination program. Chinese Medical Journal, 2007, 120:1155-1158.

17. Morita JY, Ramirez E, Trick WE. Effect of a school-entry vaccination requirement on racial and ethnic disparities in hepatitis B immunization coverage levels among public school students. Pediatrics, 2008, 121(3):e547-552.

18. Wicker $\mathrm{S}$ et al. Seroprevalence of vaccine preventable and blood transmissible viral infections (measles, mumps, rubella, polio, HBV, HCV and HIV) in medical students. Medical Microbiology and Immunology, 2007, 196:145-150.

19. Schmid K, Wallaschofski H, Drexler H. Student health policy of a German medical school results of a cross sectional study concerning student's immunity to vaccine-preventable diseases. International Journal of Hygiene and Environmental Health, 2004, 207(6):595-600.

20. Braczkowska B et al. Prevalence and basic determinants of hepatitis $\mathrm{C}$ antibodies in medical students in Katowice, Poland. Przeglad Lekarski, 2006, 63:539-542.

21. El-Gilany AH, El-Fedawy S. Bloodborne infections among student voluntary blood donors in Mansoura University, Egypt. Eastern Mediterranean Health Journal, 2006, 12:742-748.

22. Abdul Mujeeb S, Aamir K, Mehmood K. Seroprevalence of $\mathrm{HBV}, \mathrm{HCV}$ and HIV infections among college going first time voluntary blood donors. Journal of the Pakistan Medical Association, 2000, 50(8):269-270.

23. Al Faleh FZ. Hepatitis B infection in Saudi Arabia. Annals of Saudi Medicine, 1988, 8:474-480.

24. Al Faleh FZ et al. Seroepidemiology of hepatitis B virus infection in Saudi Arabian children: a baseline survey for mass vaccination against hepatitis B. Journal of Infection, 1992, 24:197-206.

25. Al-Faleh FZ et al. Integration of hepatitis B vaccine into the expanded program on immunization: The Saudi Arabian experience. Annals of Saudi Medicine, 1993, 13:231-236.

26. Al-Faleh FZ, Ramia S. Hepatitis C virus (HCV) infection in Saudi Arabia: A review. Annals of Saudi Medicine, 1997, 17:77-82.

27. Mehdi SR, Pophali A, Al-Abdul Rahim KA. Prevalence of hepatitis B and C and blood donors. Saudi Medical Journal, 2000, 21:942-944.

28. Akbar HO. Hepatitis C virus infection in Saudi Arabia. Saudi Journal of Gastroenterology, 2004, 10:127-131. 